\title{
IgA class reticulin antibodies in relatives of patients with coeliac disease
}

\author{
E. G. MAllas, N. Williamson, B. T. COOPER, AND W. T. COOKE \\ From the Nutritional and Intestinal Unit, The General Hospital, Birmingham, and the Department of \\ Experimental Pathology, Birmingham University, Birmingham
}

SUMMARY IgA class reticulin antibodies were not found in patients with Crohn's disease, ulcerative colitis, and hiatus hernia despite a significant incidence of $\mathrm{IgG}$ class reticulin antibodies. None of 56 normal healthy subjects was positive. In contrast, $13(76 \%)$ of the sera from 17 patients with coeliac disease on normal diet were positive for IgA class antibodies as were $19(20 \%)$ of 93 first degree relatives. Seventy-three relatives underwent jejunal biopsy. Grade III (flat) histology was found in 13 and, of these patients, $10(77 \%)$ showed IgA class reticulin antibody in their serum. It is suggested that determination of $\operatorname{IgA}$ class reticulin antibodies was a useful test to determine which relative must be biopsied.

The incidence of coeliac disease in first-degree relatives of coeliac patients varies between 10 and $18 \%$ (Macdonald et al., 1965; Robinson et al., 1971; Mylotte et al., 1972; Shipman et al., 1973; Stokes et al., 1976). In view of the complications of coeliac disease, such as malignancy, and the improvement in health brought about by a gluten-free diet, the detection of any affected relatives is desirable. At present, jejunal biopsy is the only acceptable method of establishing the diagnosis, but, for obvious reasons, it is not a satisfactory screening test. The need for a simpler test for diagnosis is apparent. In 1971, Seah et al. (1971a) described an antibody reacting with connective tissue components in the sera of patients with coeliac disease and in dermatitis herpetiformis. The reactivity appeared to be directed against reticulin.

With regard to the immunoglobulin class of reticulin antibodies the reports vary. Originally Seah $e t$ al. (1971a) using antihuman IgG and IgM antisera found the antibody to be IgG class. Subsequently, it has been reported to be $\operatorname{IgG}, \operatorname{IgA}$, or mixed $\operatorname{IgA}$ and IgG class with varying frequencies. The occurrence of IgM class reticulin antibody has not been reported (Seah et al., 1971b; Alp and Wright, 1971; Brown et al., 1973). Magalhaes et al. (1974), using monospecific IgA, IgG, and IgM antisera, studied patients with adult coeliac disease, a variety of other diseases, and normal subjects and have shown that the $\operatorname{IgA}$ class antibody activity was 'practically confined' to

Received for publication 16 February 1977 sera from adult coeliac patients taking a normal diet. Stevens et al. (1975) found an increased incidence of reticulin antibody in relatives of coeliac patients using polyvalent antihuman antisera. Out of 82 first degree relatives investigated by jejunal biopsy, 14 had coeliac disease of whom 12 were positive for the antibody, suggesting that this investigation might be a good screening test to detect coeliac disease in relatives. Brown et al. (1973) studying 48 coeliac children found a $67 \%$ incidence of reticulin antibody, with $15 \%$ in controls. In all the positive patients, antibody in the IgG class was found, and, in addition, in 11 of 48 coeliac patients and also in two of the 48 controls antibodies of the IgA class were also present.

In view of the apparent discrepancies concerning the reticulin antibodies, the purpose of this study was to investigate again relatives of coeliac patients, using monospecific anti-IgA and IgG antisera.

\section{Methods}

Ninety-three first-degree relatives (20 parents, 50 siblings, and 23 children) of coeliac patients have been studied, ranging in age from 13 to 62 years (mean age 37.4 years) and being 45 male and 48 female. Jejunal biopsy was obtained in 73 of them, using the Choudhury multiple biopsy capsule (Roy Choudhury et al., 1964). Those who were not biopsied either had refused or were living elsewhere in Great Britain. Histological findings were classified according to that of Roy Choudhury et al. (1964), grade III being the classical flat biopsy of coeliac 


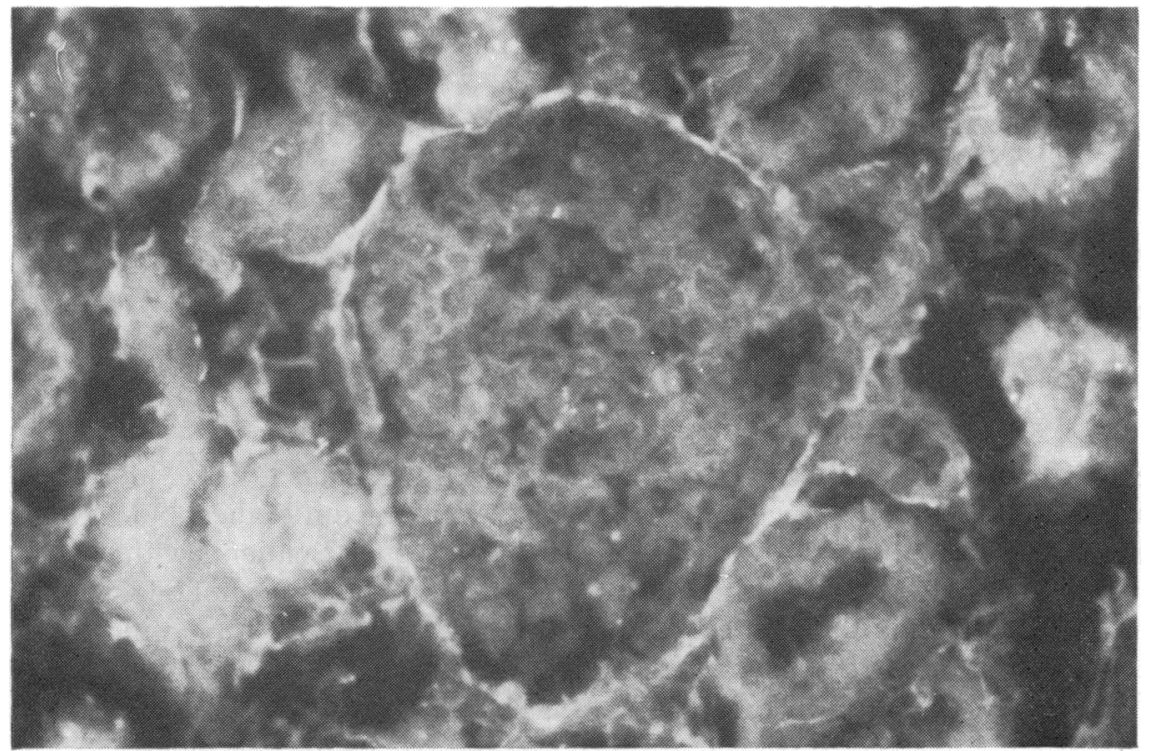

Fig. 1 Rat renal cortex showing reactivity with the parietal layer of Bowman's capsule, together with some peritubular basement membrane staining. Serum from relatives of coeliac disease patient + FITC anti-IgA, $\times 300$.

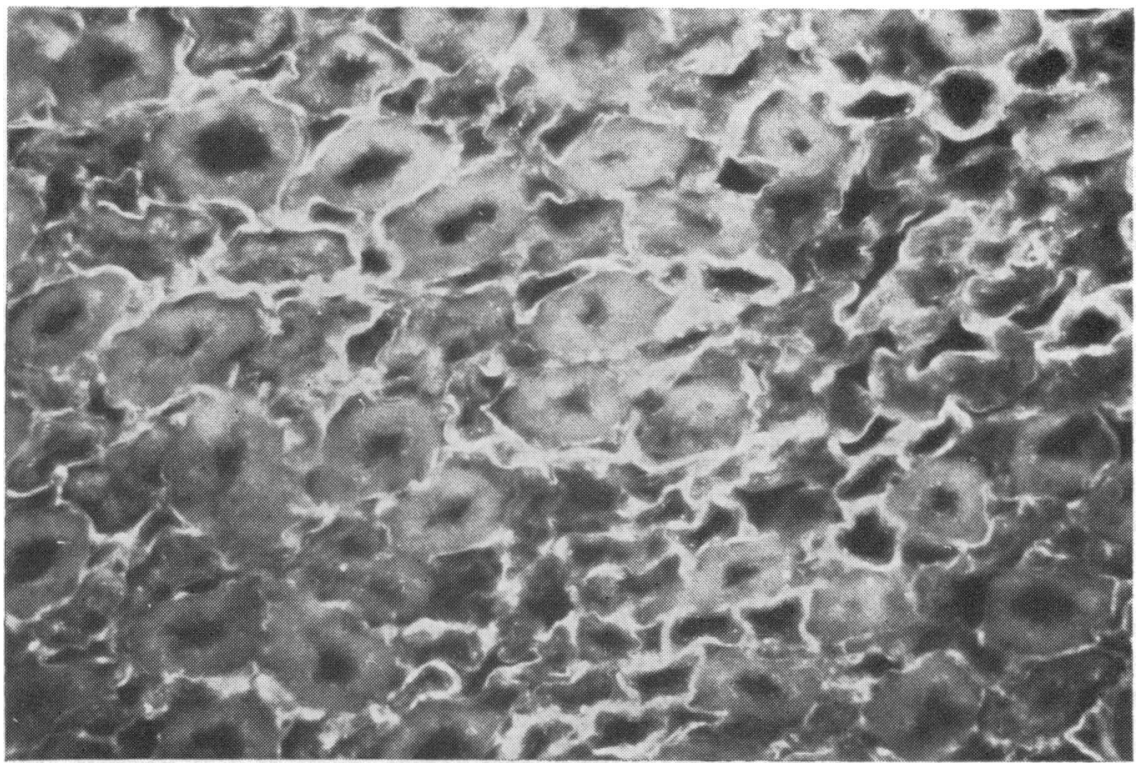

Fig. 2 Rat renal medulla. This shows the typical peritubular basement membrane staining. Coeliac disease relative's serum + FITC anti-IgA, $\times 120$.

disease, grade II being moderately abnormal, grade I having minor non-specific abnormalities, and grade 0 normal.

Peripheral blood samples were obtained and the serum separated and stored at $-20^{\circ} \mathrm{C}$. For the estimation of the reticulin antibodies sera were diluted 1 in 5 using a standard indirect immunofluorescent technique (Seah et al., 1971a) on frozen sections of rat kidney, liver, stomach, and salivary gland. Commercially available rabbit fluorescent conjugated monospecific antihuman IgA (Wellcome Laboratories) was used at a 1 in 10 dilution. Monospecific sheep antihuman IgG (Department of Experimental Pathology, University of Birmingham) was conjugated with fluorescein and used as previously described (Williamson et al.,1976).The reticulin antibody was considered to be positive if the characteristic pattern (Seah et al., 1971a) was seen 
Table Reticulin antibodies of IgA and IgG class

\begin{tabular}{|c|c|c|c|c|c|c|}
\hline Group & No. & $\begin{array}{l}\operatorname{IgA} A \\
(\text { no. })\end{array}$ & $\begin{array}{l}I g G \\
\text { (no.) }\end{array}$ & $\begin{array}{l}I g G+I g A \\
(\text { no. })\end{array}$ & $\begin{array}{l}\text { All positive } \\
\text { reticulin } \\
\text { antibodies } \\
(\%)\end{array}$ & $\begin{array}{l}\text { Total IgA } \\
\text { positives } \\
(\%)\end{array}$ \\
\hline Control & 56 & $\mathbf{0}$ & 1 & $\mathbf{0}$ & $1 \cdot 8$ & $\mathbf{0}$ \\
\hline Crohn's & 19 & $\mathbf{0}$ & 2 & 0 & $10 \cdot 5$ & $\mathbf{0}$ \\
\hline Ulcerative colitis & 22 & 0 & $\mathbf{0}$ & 0 & 0 & 0 \\
\hline \multicolumn{7}{|l|}{ Coeliac disease } \\
\hline Gluten-free & 7 & 0 & 0 & 1 & $14 \cdot 3$ & $14 \cdot 3$ \\
\hline Relatives (total) & 93 & 13 & 10 & 6 & $31 \cdot 2$ & $20 \cdot 4$ \\
\hline Relatives (biopsied) & 73 & 10 & 6 & 6 & $30 \cdot 1$ & $21 \cdot 9$ \\
\hline Grade 0 & 26 & 2 & 3 & 2 & 26.9 & $15 \cdot 4$ \\
\hline Grade I & 30 & 0 & 3 & 1 & $13 \cdot 3$ & $3 \cdot 3$ \\
\hline Grade II & 4 & 1 & 0 & 0 & $25 \cdot 0$ & $25 \cdot 0$ \\
\hline Grade III & 13 & 7 & 0 & 3 & 76.9 & 76.9 \\
\hline
\end{tabular}

staining the peritubular connective tissue and Bowman's capsule in the kidney (Figs 1 and 2), the sinusoids and portal tract in the liver, and between the gastric glands in the stomach. This antibody corresponds with the endothelial basement membrane antibody of Williamson et al. (1976) and to the R1 antibody of Rizzetto and Doniach (1973). Kidney sections were the best substrate organ and sometimes it was the only organ which was positive. The antibody was also sought in the sera of 17 coeliac patients before treatment, in seven coeliac patients on a gluten-free diet, 19 with Crohn's disease, 22 with ulcerative colitis, 19 with hiatus hernia known to be IgG positive, and 56 healthy subjects-doctors, nurses, and laboratory personnel -who were used as controls. All the serum samples examined were randomised without knowing the biopsy or other results of the subject. Positive and negative control sera were always used with each batch of tests. The HLA antigens were determined in each of the relatives using a modification of the micro-lymphocytotoxicity test of Terasaki and McClelland (1964).

\section{Results}

The Table shows the incidence of the reticulin antibody for both IgA and IgG class in 56 normal controls in 17 coeliac patients on a normal diet, seven on a gluten-free diet, 19 with Crohn's disease, 22 with ulcerative colitis, and in 93 relatives of coeliac patients. The same Table shows also the incidence of the antibody in 73 of the relatives who had had jejunal biopsy examination, grouped according to their biopsy grade. Eleven out of 17 coeliac patients were $\operatorname{IgA}$ class antibody positive, and one IgG and two mixed IgA and IgG-that is, 13 out of 17 were positive to IgA class antibody. From the seven coeliac patients on gluten-free diet, one was positive for both IgA and IgG class. The overall incidence of the reticulin antibodies (IgA and/or IgG class) in the 93 relatives studied was $31.1 \%$ which was significantly greater than the $1.7 \%$ found in the normal population (one IgG class antibody from 56 normal sera, $\mathrm{P}<0.005)$. IgA class was present in 19 relatives $(20.4 \%)$ of whom $13(14 \%)$ were IgA alone and six $(7 \%)$ were both IgA and IgG. Ten $(10.7 \%)$ were IgG only.

Of the 73 relatives subjected to biopsy (Table) 22 $(30 \%)$ had IgA and/or IgG antibodies of whom 10 $(14 \%)$ were $\operatorname{IgA}$ alone, six $(8 \%)$ were $\operatorname{IgG}$ and $\operatorname{IgA}$, and six $(8 \%)$ were IgG alone. Thirteen subjects $(18 \%)$ had grade III histology, compatible with coeliac disease. Ten of those $13(77 \%)$ were IgA type reticulin antibody positive of whom three were IgG class positive also. Four subjects had grade II histology, one of whom had IgA class antibodies. Of the 30 who were grade I histologically, four had the IgG class and one of them had IgA as well. Of 26 with grade 0 biopsy, there were three IgG only positive, two with IgA class only, and two subjects with both. This represents a significantly increased incidence of the IgA class antibody in grade III histology compared with those relatives who had grade 0 and grade I $(P<0.005)$. No statistical differences were found when comparing the IgG class antibody. Of the five relatives with IgA class antibody positive and with non-specific histological findings, increased plasma cell counts in the lamina propria in the range found in treated coeliac subjects were present in three patients (IgA and IgG positive), in whom the epithelial lymphocytes were increased in one and at the upper limits of normal in a second. In the remaining two patients (IgA positive only) the counts were completely normal. Increased cell counts were noted in many of the relatives submitted to biopsy with non-specific histological findings and negative IgA reticulin antibodies, while the incidence of HLA-8 was also increased over that found in normal control subjects. 


\section{Discussion}

The findings in this study are similar to, although somewhat greater than, those of Stevens et al. (1975), who, using polyvalent antihuman antiserum, found that the reticulin antibody was positive in $18 \%$ of the 121 relatives of the coeliac patients studied. In our study, of the relatives who underwent jejunal biopsy, $18 \%$ had histological findings compatible with coeliac disease, of whom $77 \%$ had IgA class antibody activity. In the known untreated coeliac subjects who were studied, the IgA class antibody was the predominant class. These results confirm the findings of Magelhaus et al. (1974). They are, however, different from those of Seah et al. (1971b) and Brown et al. (1973) who found that the IgG class predominated in children with coeliac disease. For this we have no obvious explanation, but differences in age may be important. Magalhaes et al. (1974) reported no IgA class reticulin antibody positives in a variety of diseases and in the normal control subjects they studied. In our control subjects, who included patients with Crohn's disease, ulcerative colitis, and hiatus hernia, no example of a positive IgA class reticulin antibody was encountered, though IgG class antibodies were present in a number.

According to our results, by performing the IgA class reticulin antibody test we could pick up 10 out of 13 asymptomatic relatives with coeliac disease and one with a moderately abnormal jejunal biopsy (grade II), but there were three $(4 \%)$ false negatives (of grade III histology) and five (7\%) false positive (grade 0 or I histology). In the five relatives with IgA class antibody positive and normal jejunal histology, cell counting of the epithelial and the lamina propria showed a significant increase in plasma cell counts in the lamina propria in three patients and of intraepithelial lymphocytes in one patient. Such patients must be regarded as potential coeliac patients and will be kept under review. There were no distinguishing clinical features in the three relatives with grade III jejunal histology who were reticulin antibody negative. One, who had no symptoms, refused a gluten-free diet, one showed an excellent response to a gluten-free diet, and the third had a poor response. All three had HLA antigens A1.B8.

In conclusion, our data support the idea that the IgA class anticonnective tissue antibody test could be a useful screening test in relatives of coeliac patients to help to decide who must have a jejunal biopsy.

\section{References}

Alp, M. H., and Wright, R. (1971). Autoantibodies to reticulin in patients with idiopathic steatorrhoea, coeliac disease, and Crohn's disease, and their relation to immunoglobulins and dietary antibodies. Lancet, 2, 682-685.

Brown, I. L., Ferguson, A., Carswell, F., Horne, C. H. W., and MacSween, R. N. M. (1973). Autoantibodies in children with coeliac disease. Clinical and Experimental Immunology, 13, 373-382.

Macdonald, W. C., Dobbins, W. O., and Rubin, C. E. (1965). Studies of the familial nature of celiac sprue using biopsy of the small intestine. New England Journal of Medicine, 272, 448-456.

Magalhaes, A. F. N., Peters, T. J., and Doe, W. F. (1974). Studies on the nature and significance of connective tissue antibodies in adult coeliac disease and Crohn's disease. Gut, 15, 284-288.

Mylotte, M., Egan-Mitchell, B., Fottrell, P. F., McNicholl, B., and McCarthy, C. F. (1972). Familial coeliac disease. (Abstract). Quarterly Journal of Medicine, 41, 527-528.

Rizzetto, M., and Doniach, D. (1973). Types of 'reticulin' antibodies detected in human sera by immunofluorescence. Journal of Clinical Pathology, 26, 841-851.

Robinson, D. C., Watson, A. J., Wyatt, E. H., Marks, J. M., and Roberts, D. F. (1971). Incidence of small-intestinal mucosal abnormalities and clinical coeliac disease in the relatives of children with coeliac disease. Gut, 12, 789-793.

Roy Choudhury, D. C., Nicholson, G. I., and Cooke, W. T. (1964). Simple capsule for multiple intestinal biopsy specimens. Lancet, 2, 185-186.

Seah, P. P., Fry, L., Hoffbrand, A. V., and Holborow, E. J. (1971a). Tissue antibodies in dermatitis herpetiformis and adult coeliac disease. Lancet, 1, 834-836.

Seah, P. P., Fry, L., Rossiter, M. A., Hoffbrand, A. V., and Holborow, E. J. (1971b). Antireticulin antibodies in childhood coeliac disease. Lancet, 2, 681-682.

Shipman, R. T., Williams, A. L., Kay, R., and Townley, R. R. W. (1973). Quoted in Clinical Gastroenterology, 2, 549 and 551. In Clinics in Gastroenterology, vol. 2. Edited by R. G. McConnell. Saunders: London.

Stevens, F. M., Lloyd, R., Egan-Mitchell, B., Mylotte, M. J., Fottrell, P. F., Wright, R., McNicholl, B., and McCarthy, C. F. (1975). Reticulin antibodies in patients with coeliac disease and their relatives. Gut, 16, 598-602.

Stokes, P. L., Prior, P., Sorahan, T. M., McWalter, R. J., Waterhouse, J. A. H., and Cooke, W. T. (1976). Malignancy in relatives of patients with coeliac disease. British Journal of Preventive and Social Medicine, 30, 17-21.

Terasaki, P. I., and McClelland, J. D. (1964). Microdroplet assay of human serum cytotoxins. Nature, 204, 998-1000.

Williamson, N., Asquith, P., Stokes, P. L., Jowett, A. W., and Cooke, W. T. (1976). Anticonnective tissue and other antitissue 'antibodies' in the sera of patients with coeliac disease compared with the findings in a mixed hospital population. Journal of Clinical Pathology, 29, 484-494. 